異所性 adrenocorticotropic hormone (ACTH), melanocyte stimmulating hormone (MSH), calcitonin (CT) 産生を 伴つた Sipple 症候群の 1 例

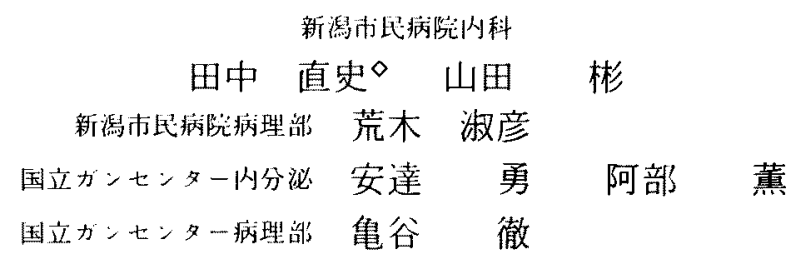

\title{
A CASE OF SIPPLE'S SYNDROME WITH ECTOPIC PRODUCTION OF ACTH, MSH AND CALCITONIN
}

Naoshi TANAKa, MD, Akira Yamada, MD and Toshihiko ARAKI, MD

Niigata City Hospital, Niigata

Isamu AdACHI, MD Kaoru A bE, MD and Tohru KAMEYA, MD

National Cancer Center, Tokyo

\begin{abstract}
概要 14年間糖尿病でインスリン治療を受けていた58才の患者が，特別な前駆症状るなく麻疩性腸閉 塞, 高血桾ヶトーシスで緊急入院し, 間もなくンョック症状となり盲腸摟造成術を行なつたが, 術後急 性腎不全を併発し死亡した。死亡直前に褐色細胞腫の合併が訩断されたが，種々の治療に奏効せず不幸 な転㴆をとつた。剖検の結果，両側副腎に巨大な褐色細胞腫が存在したほかに，甲状腺踓様癌 (MCT) が認められ，典型的なSipple症候群であつたことが確認された．内分泌検査で血中カルチトニン(CT)

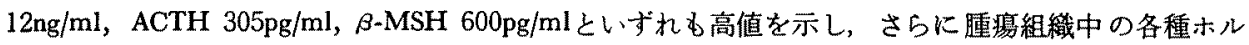
モンを湘定した結果，MCT組織中にCT $1.8 \mathrm{mg} /$ wet $\mathrm{g}$, ACTH $9.9 \mathrm{ng} /$ wet $\mathrm{g}, \beta$-MSH $57.1 \mathrm{ng} /$ wet $\mathrm{g}$ また，褐色細胞腫からもCT $215.8 \mathrm{ng} /$ wet g, ACTH $617 \mathrm{ng} /$ wet $\mathrm{g}, \beta-\mathrm{MSH} 500 \mathrm{ng} /$ wet g の存在が証明 された，一方蛍光抗体法でMCT組織中にCT抗体とACTH抗体に，褐色細胞腪組織中にもCT抗体に反 応する陽性細胞が認められた。従つて，本症は異所性ACTH， $\beta$-MSH産生甲状腺髄槏癌に異所性CT， $\mathrm{ACTH}, \beta-\mathrm{MSH}$ 産生褐色細胞皇を合併した非常に興味深い莚例であつた。 なお，生存中の家族につい てCa負荷試験等で娭索したところ，患者の次女にCTの異常反応が認められ甲状腺全摘術で両側葉に $2 \sim 3 \mathrm{~mm}$ 大の微小MCTが発見され，術後 3 年を経過した現在まで再発，転移の所見は認められざ健 在である.
\end{abstract}

\section{1. 緒言}

1961年にSippleが甲状腺癌と褐色細胞腫の合併 率が高いことを初めて指摘し，1968年にいた

[昭和51年10月17日 第59回信越地方会推薦]
りSteinerらによりこの疾患をmultiple endocrine neoplasia (MEN), type 2 といら概念でとら充, 以 来Sipple症候群として知られるよらになつた。 の後PearseによりAPUD (amine precursor uptake 
and decarboxylation) の概念が確立され，1969年 にSzijjがACTHを産生分泌する甲状腺髄样癌に初 めてAPUDoma と名付けた。，甲状腺䯣様癌や褐色 細胞盾はいずれもAPUDoma としての共通の性格 をもち，種々のアミンやポリペプチドホルモンを 産生，放出することが報告されている。しかし，甲 状腺䯣棣癌に褐色細胞腫を合併したSipple症候群 において，おのおのの腫瘍についてACTH，MSH やCTが同時に産生されている事を検討した症例 の報告は見当らない，著者らは典型的なSipple症 候群でおのおのの腫瘍からACTH， $\beta$-MSH，CT を同時に異所性に産生していた非常に與味深い1 例を経験し，これはmultiple endocrine neoplasia (MEN) および腫瘍の異所性ホルモン産生を考兄 る上で貴重な症例と考える。

\section{2. 症例}

患者： 俵 $\bigcirc$ 春 $\bigcirc ， 58$ 才，男，公務員.

主訴：全身倦怠，悪心，呕吐，便秘。

家族歴：後述する.

既往歴：25才のとき胃潰瘍で内科的治療を受 けたが，高血圧や甲状腺腫の既往はなかつた。

現病歴：13年前（45才）に，糖尿病の診断を 受けて以来インスリン療法を続けていた．5年前 頃から多汗傾向が出現していたが，入院 1 週間前 より動悸を自覚し，特に入浴時に強く感しるよう になり，数日前からは悪心，食後呕吐や便泌を訴 光るようになつた。 むなく経口摄取が不可能と なり，インスリン治療も中断していたところ，糖 疗病と腸閉塞症状が増悪し, 昭和51年 1 月 20 日当 院に紹介されて緊急入院した。

入院時所見：身長 $168 \mathrm{~cm}$ ，体重 $49 \mathrm{~kg}$ ，体温 $36.6^{\circ} \mathrm{C}$, 脈拍 $96 /$ 分 整, 微弱で血圧は右 $154 / 112$ $\mathrm{mm} \mathrm{Hg}$, 左164/124mm Hgであつた，意識は清明であつ たが全身のやせと衰弱が著明で，皮膚は湿潤し四 肢の冷感があつた：また，全身の皮膚，眼，口腔 内に結節户色素沈着は認めず，甲状腺は全体に弾 性硬で，両葉に $2.0 \times 2.5 \mathrm{~cm}$ 大の尰瘤を触知できた が頝部など表在性リンパ節の董大はなかつた。打 聴診上，心，肺に異常所見はなく，腹部は全体に
膨满し氏痛はなかつたが，上腹部に瓷塊様の腫瘤 が触知された。神経学的に異常はなく下肢に浮腫 は認めず，その他Cushing症候 や先端巨大等の内 分泌疾患を思わす異常所見むなかつた。

入院後経過： 腹部X線撮影などの検査により 麻痺性腸閉塞と糖尿病の増悪によるヶトーシス， 脱水と診断し，生食水と糖分を主体にした輸液に レギュラーインスリンによる治療を試みたが，腸 閉塞が増悪しショック状態となり緊急に盲腸㾇造 成術を行なつた，術前VMAが定性で陰性であつ たが，術後尿中アドレナリン3400，ノルアドレナ リン $5283 \mu \mathrm{g} /$ 日と非常な 高值であつたことがわか り褐色細胞腫と診断された. phenoxybenzamineゃ propranololなどの治㞠を行なつたが，末梢循環不 全の改善が認められず腎不全状態となり入院18日 目に死亡した。

入院時一般検查成績：表 1 に示したよらに空 腹時血糖は $500 \mathrm{mg} / \mathrm{dl}$ 之高值で 尿蛋白，尿糖之尿了 セトン体はいずれる陽性であつた．脱水のため 血液が濃縮され白血球増加が認められたが，その 分類にはとくに 異常所見を認めなかつた。 また GOT 55単位, LDH 745単位と軽度に上昇し，総 コレステロール352mg/dl, 中性脂肪 $155 \mathrm{mg} / \mathrm{dl}, \beta-1)$ ポ蛋白 $1000 \mathrm{mg} / \mathrm{dl}$ と脂質代謝の異常がみられた，一 方, 血清電解質はCa $9.0 \mathrm{mg} / \mathrm{dl}$, 無機 $\mathrm{P} 2.9 \mathrm{mg} / \mathrm{dl}$, $\mathrm{K} 5.3 \mathrm{mEq} / l$ と正常で特に低K血性アルカローシ スの所見はなかつた，尿素窒素 $52 \mathrm{mg} / \mathrm{dl}$ ，クレアチ ニン1.3mg/dlであつたが， 1 日尿量平均 $2270 ， 24$ 時間内因性クレアチニンクリアランス $61 l / \mathrm{d}$ と特 に強い腎機能障害は認めなかつた。

内分泌検查成績（表 2）：急な転帰をとつた ため充分な検索がなされなかつたが，24時間尿中 アドレナリン $3400 \mu \mathrm{g}$ ，ノルドレナリン $5283 \mu \mathrm{g}$ と ともに著增して㧍り，中間代謝産物のメタネフ リン $1.21 \mathrm{mg} ， ノ ル メ タ ネ フ リ ン 1.22 \mathrm{mg}$ ，終末代謝 産物のVMAは $16.1 \mathrm{mg}$ と軽度の上昇を認めた。血 中各種 ホルモンをradioimmunoassayで測定した ところ, CT $12 \mathrm{ng} / \mathrm{ml}$, ACTH $305 \mathrm{pg} / \mathrm{ml}, \beta-\mathrm{MSH}$ $600 \mathrm{pg} / \mathrm{ml} ，$ PTH $0.92 \mathrm{ng} / \mathrm{ml}$ と異常な高値を示し 
表 1. 入院時検査成績

\begin{tabular}{|c|c|c|c|c|c|}
\hline 空腹時血糖 & $500 \mathrm{mg} / \mathrm{dl}$ & 血液化学 & & 血游総蛋白 & $7.1 \mathrm{~g} / \mathrm{dl}$ \\
\hline 尿＼cjkstart登白 & $(\#)$ & $\mathrm{Na}$ & $133 \mathrm{mEq} / t$ & $\{$ Alb. & $62.0 \%$ \\
\hline 解 & ( $\#)$ & $\mathrm{K}$ & $5.3 \mathrm{mEq} / \mathrm{l}$ & GI. & $5.5 \%$ \\
\hline アセトン体 & $(+)$ & $\mathrm{Cl}$ & $90 \mathrm{mEg} / \mathrm{l}$ & $\alpha_{2}$ & $10.8 \%$ \\
\hline VMA定性 & $(-)$ & $\mathrm{Ca}$ & $9.0 \mathrm{mg} / \mathrm{dl}$ & $\beta-$ & $4.1 \%$ \\
\hline 末梢血 & & 無機P & $2.9 \mathrm{mg} / \mathrm{dl}$ & $\beta$ & $8.6 \%$ \\
\hline 赤血球数 & $529 \times 10^{4} / \mathrm{mm}^{3}$ & BUN & $52 \mathrm{mg} / \mathrm{dl}$ & $\gamma$ & $8.7 \%$ \\
\hline へモグロビン & $17.7 \mathrm{~g} / \mathrm{dl}$ & $\mathrm{Cr}$ & $1.3 \mathrm{mg} / \mathrm{dl}$ & \multirow{10}{*}{\multicolumn{2}{|c|}{ 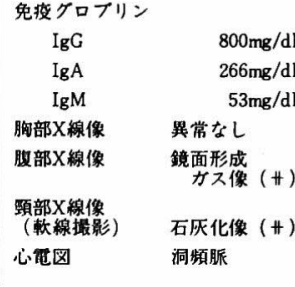 }} \\
\hline ヘマトクリット & $54 \%$ & GOT & $55 \mathrm{U}$ & & \\
\hline 白血球数 & $12000 / \mathrm{mm}^{3}$ & GPT & $20 \mathrm{U}$ & & \\
\hline (桿状球 & $1 \%$ & Alk-P-ase & $8.8 \mathrm{U}$ & & \\
\hline 分葉核 & $88 \%$ & $\mathrm{LDH}$ & $745 \mathrm{U}$ & & \\
\hline 好酸球。 & $0 \%$ & LAP & $176 \mathrm{U}$ & & \\
\hline 好塩基球 & $0 \%$ & $\gamma$-GTP & $18 \mathrm{U}$ & & \\
\hline 単球 & $5 \%$ & ch.E. & $\Delta \mathrm{pH} \quad 0.95$ & & \\
\hline リンハハ球 & $6 \%$ & $\mathrm{Bil}$ & $0.95 \mathrm{mg} / \mathrm{dl}$ & & \\
\hline 血小板 & $22.8 \times 10^{4} / \mathrm{mm}^{3}$ & TTT & $0.7 \mathrm{U}$ & & \\
\hline 血沈 $6 \mathrm{~mm} 1$ 時間値 & $20 \mathrm{~mm} 2$ 時間值 & $\mathrm{ZTT}$ & $1.5 \mathrm{U}$ & & \\
\hline 血被カス & & CCLF & $(-)$ & & \\
\hline $\mathrm{pH}$ & 7.423 & CRP & $(-)$ & & \\
\hline $\mathrm{PO}_{2}$ & $82.4 \mathrm{mmHg}$ & T.chol. & $352 \mathrm{mg} / \mathrm{dl}$ & & \\
\hline $\mathrm{PCO}_{2}$ & $36.5 \mathrm{mmHg}$ & T.G. & $155 \mathrm{mg} / \mathrm{dl}$ & & \\
\hline $\mathrm{HCO}_{3}$ & $22.4 \mathrm{mEq} / l$ & $\beta . \mathrm{L}$ & $1000 \mathrm{mg} / \mathrm{dl}$ & & \\
\hline \multirow[t]{3}{*}{ B.E. } & \pm 0 & アミラーセ & & & \\
\hline & & 血清 & $86 \mathrm{U} / \mathrm{dl}$ & & \\
\hline & & 尿 & $86 \mathrm{U} / \mathrm{dl}$ & & \\
\hline
\end{tabular}

表 2. 内分泌検査成樍

\begin{tabular}{llcl}
\hline urinary & adrenaline & $3400 \mu \mathrm{g} / \mathrm{d}$ & $($ normal \\
& noradrenaline & $5283 \mu \mathrm{g} / \mathrm{d}$ & $(10 \leqq n \leqq 90)$ \\
& metanephrine & $1.21 \mathrm{mg} / \mathrm{d}$ & $(0.01 \leqq n \leqq 0.03)$ \\
& normetanephrine & $1.22 \mathrm{mg} / \mathrm{d}$ & $(0.05 \leqq n \leqq 0.40)$ \\
& VMA & $16.1 \mathrm{mg} / \mathrm{d}$ & $(2 \leqq n \leqq 8)$ \\
\hline plasma & calcitonin & $12 \mathrm{ng} / \mathrm{ml}$ & $($ normal $\leqq 0.05)$ \\
& cortisol & $80 \mu \mathrm{g} / \mathrm{dl}$ & $(7 \leqq n \leqq 16)$ \\
& PTH & $0.92 \mathrm{ng} / \mathrm{ml}$ & $(\mathrm{n} \leqq 0.5)$ \\
& ACTH & $305 \mathrm{pg} / \mathrm{ml}$ & $(\mathrm{n} \leqq 100)$ \\
& $\beta-M S H$ & $600 \mathrm{pg} / \mathrm{ml}$ & $(\mathrm{n} \leqq 100)$ \\
& GH & $2.1 \mathrm{ng} / \mathrm{ml}$ & $(\mathrm{n} \leqq 5)$ \\
& TSH & $4.3 \mu \mathrm{U} / \mathrm{ml}$ & $(\mathrm{n} \leqq 10)$ \\
\hline serum & TBC index & 0.98 & \\
& T 4 & $5.7 \mu \mathrm{g} / \mathrm{dl}$ & \\
& thyroid test & $(-)$ & \\
& microsome test & $(-)$ & \\
\hline
\end{tabular}

たが，その他の下垂体前葉 ホルモンである $\mathrm{GH}$ ， TSHはいずれも正常範囲内の值であつた。 また， 午前中コルチゾールは $80 \mu \mathrm{g} / \mathrm{dl}$ と高值であつたが， 甲状腺機能は特に異常を認めなかつた。

\section{剖検所見：}

1）甲状腺；重量35 g で腫大はなく，両葉の 中央やや上部に対称性に腫瘍が存在した。腫瘍は 割面で右 $1.8 \times 2.6 \mathrm{~cm}$, 左 $2.0 \times 2.5 \mathrm{~cm}$ 大で境界鮮明

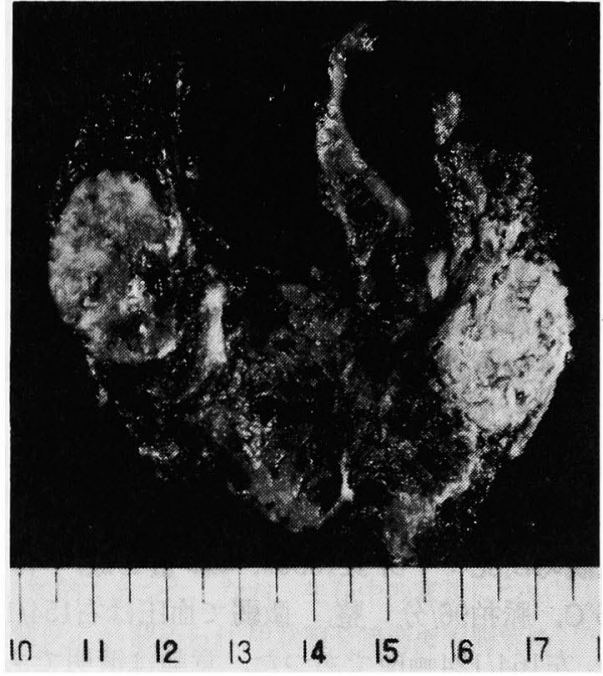

図 1 .甲状腺の肉眼写真, 両葉にほ5゙等大の腫瘤を 認める。

かつ灰白色充実性の 肉眼所見を示していた（図 1). 病理組織所見は典型的な髄様癌で, 多角形な いし円形の細胞が充実性に增殖しており, 一部で は索状構造を呈し核分裂像はみられず，硝子化の 


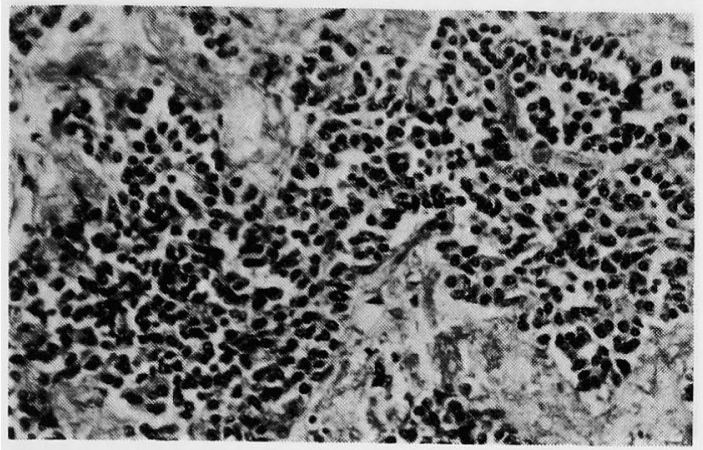

図 2.甲状腺䯣様癌の組織像。アミロイドを伴う線 維性間質の中に腫湯細胞が充実性ないし索状配列を 示す. $\mathrm{H} \& \mathrm{E} \times 250$.

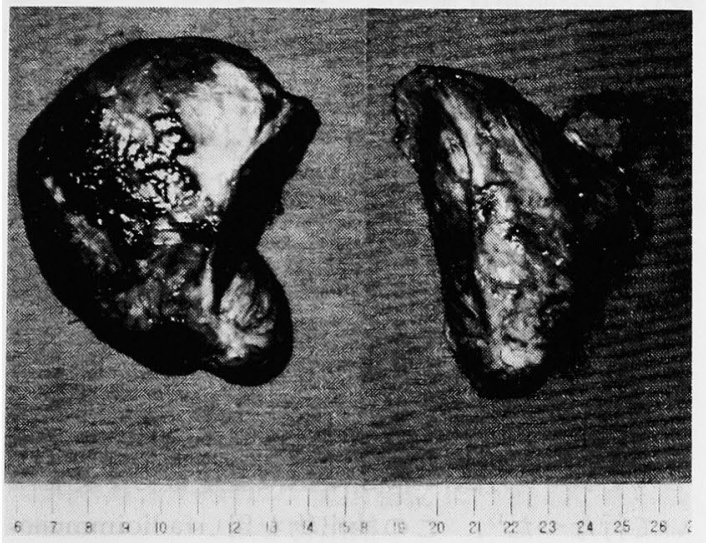

図 3 a. 副腎の肉眼所見，両側表面を示す.

強い間質を有していた（図 2 ).ささらにcongo-red 染色でアミロイドの沈着が確認された。付近のリ ンパ節に転移の所見が認められた。

2）副腎；両側に腫瘍を認め，左右いずれの 副腎もほとんど全体が腫瘍で占められて抢り，右 側 $110 ` \mathrm{~g}$, 左側60 g の重量であつた. 割面では腫 瘍が大部分を占めその中心は壊死に陥つていた。 皮質は腫瘍により圧排され菲薄化していた（図 3 ). 組織学的には腫瘍は充実性で, 間質は毛細 血管様の細い血管のみから成り, 腫瘍細胞は索状 ない乙腺房様構造をとつていた（図 4). 個々の 細胞は胞体豊富でクロマチン量が多く明るい核を もち，核分裂像はみられなかつた。腫瘍細胞は凍

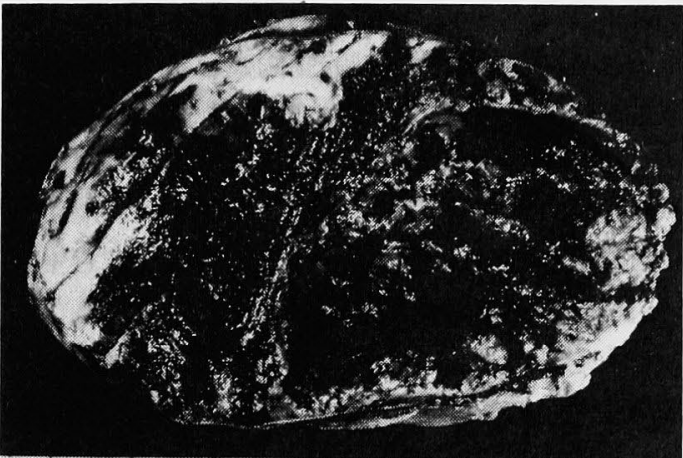
$11 \quad 12$
$213 \quad 4$
156
17. 18

図 3 b. 右副腎の割面。大部分腫煬で占められ, 中 心部に出血・壊死が強い. 副腎皮質は菲薄化し, ほ とんどえない。

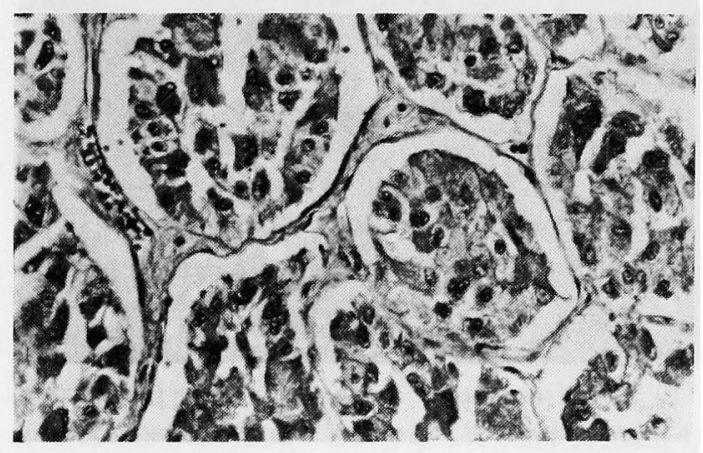

図 4. 副腎褐色細胞腫の組織像. $\mathrm{H} \& \mathrm{E} \times 250$.

結乾燥ホルマリン蒸気処理によるカテニールフミ ソ蛍光およびクローム親和性を示し, 褐色細胞腫 であることが確かめられた。なお，副腎皮質は腫 瘍に圧排されている部分が大部分で，過形成の有 無を適確に判断することは困難であつた。

3）下垂体；コルチゾール過剩分泌時にみら れる Crooke 変性を認めたが，腺腫は存在してい なかつた。

4）膵葴；重量50 g と小さく脺ラ島も萎縮性 であつた。な括，膵管周囲に甲状腺髄様癌の小さ な転移巣を認めた。

5）副甲状腺；肉眼的に腫大した腺腫は見い 出しえず，少なくとも肥大，過形成などは認めら 
れなかつた。

その他消化管には機椷的腸閉塞を扢こす原因と なる器質的変化はなく, 肝, 腎, 心, 肺, 骨, 前立 腺，睾丸などにも転移や特別な異常所見は認めな かつたが，脾蔵が $7 \mathrm{~g}$ と非常に小さかつた。

腫痹の免疫組織化学的検索： 腫瘍を含む甲状 腺組織への多数の切片を蛍光抗体法で検索したと ころ, 腫瘍蜂巣内細胞の大半の胞体 がCTが陽性 であつた（図 $5 \mathrm{a}$ )。一方，腫瘍部からなかなり離 れた甲状腺内にCT陽性細胞群が一部は集簇し，二 部は傍沪胞部分に一致して散在性に認められ， C 細胞過形成巣の所見が存在していた（図 5 b).

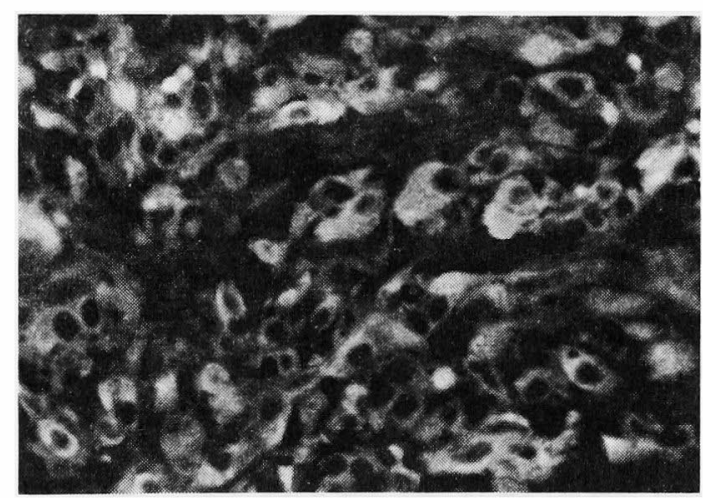

図 $5 \mathrm{a}$. 甲状腺煘様癌. カルチトニン陽性細胞を示 す蛍光抗体法写真.ほとんどの細胞の胞体内が陽性 所見を示す. $\times 400$

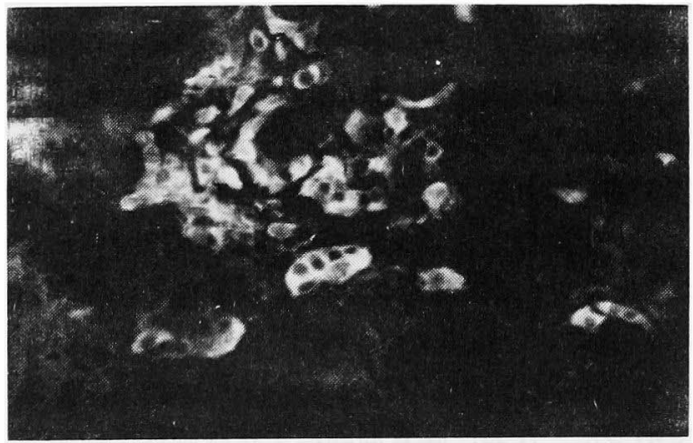

図 $5 \mathrm{~b}$. 主腫瘍から離れた甲状腺内 $\mathrm{C}$ 一細胞通形成 巣. カルチトニン陽性細胞を示す蛍光抗体法写真. 各陽性細胞は沪胞上皮の一部を置換している。 $\times 260$

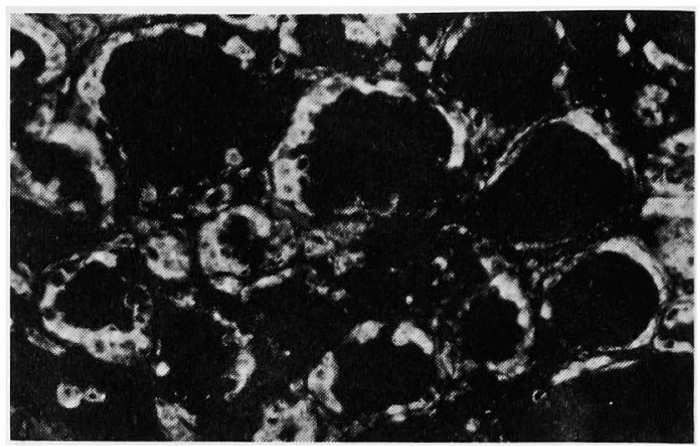

図 6. 甲状腺䯣様癌. ACTH陽性細胞を示寸监光抗 体法写真. 汇胞細胞を置換する如く陽性細胞が增生 している. × 260 .

た，ACTH 抗体を用いた蛍光抗体法では，沪胞 構造を保存したまま増生せる腫瘍細胞にACTH陽 性所見を認めた（図6)。褐色細胞腫組織も同様 の操作を行ないヒトCT抗体に 対し多くの 細胞が 陽性であつたが，ACTH抗体に対しては蛍光は認 められなかつた.

\section{腫瘍組織中のホルモン測定 :}

1）測定方法 ； 死後 1 時間後に剖検された各 臓器組織を, 直ちにドライアイスで涷結させ抽出 時までー $20^{\circ} \mathrm{C}$ に保存した。抽出方法はすでに報告 したPayneの方法に準 じて 組織湿重量約 $1 \mathrm{~g}$ を用 いて行なつた 。 この抽出物を用いradioimmunoassayでCT，ACTH， $\beta$-MSH，PTHを測定した. この場合非特異的反応を避けるため, 抽出物を 3 用量以上にわたり希釈し，2 点以上において dose response が認められたものについてのみ当該ホル モンが存在すると判定した.

2）測定結果； 表 3 K甲状腺髄様癌, 副腎褐 色細胞腫組織中 のCT, ACTH, $\beta-\mathrm{MSH}, \mathrm{PTH} の$ 測定成績を示した。骨道様癌組織中CT含有量 1800

\section{表 3．腫瑒組織中のホルモン}

\begin{tabular}{c|cccc}
\hline \multirow{2}{*}{ Organ } & tissue & contents & \multicolumn{2}{c}{ (ng/wet g) } \\
CT & ACTH & $\beta-\mathrm{MSH}$ & PTH \\
\hline thyroid medullary ca. & $1800 \times 10^{3}$ & 9.9 & 57.1 & ud \\
pheochromocytoma & 215.8 & 617.1 & 500 & ud \\
normal liver & ud & ud & ud & nm \\
\hline \multicolumn{4}{c}{ ud : undetectable } \\
nm: not measured
\end{tabular}


$\mu \mathrm{g} /$ wet $\mathrm{g}$ と異常な高値を示した。またACTHが $9.9 \mathrm{ng} /$ wet $\mathrm{g}, \beta$-MSHが $57.1 \mathrm{ng} /$ wet $\mathrm{g}$ とАCTH と $\beta$-MSHが同時に産生されていた。一方，褐色細 胞腄組織中にもCT 215.8ng/wet g, ACTH 617.1 $\mathrm{ng} /$ wet $\mathrm{g}, \beta-\mathrm{MSH} 500 \mathrm{ng} /$ wet $\mathrm{g}$ と同様にこれら 3 種のホルモンが同時に産生されていた。 しかし PTHはこれら畽瘍中には存在していなかつた。 さ らにコントロール用の患者肝䁍組織についてこれ ら3種のホルモンを測定したが，いずれも測定限 界以下の值を示した。

3）ゲル沪過法によるsize heterogenityについ ての検討； 褐色細胞腫組織中に高濃度で存在し たACTH， $\beta$-MSH，CTについてsize heterogenity について検討するため，抽出物 をSephadex G50 カラム $(1.6 \times 60 \mathrm{~cm})$ を用いてゲル沪過した成績 を図7に示した。各フラクションを ${ }^{1-24} \mathrm{ACTH}$, ${ }^{11-24} \mathrm{ACTH}$ K特異的に反応するACTH抗体を用い （ $\mathrm{N}$ 端側測定），また ${ }^{1-39} \mathrm{ACTH} ，{ }^{25-39} \mathrm{ACTH}$ 亿特異 的に反応する抗体を用いた（C端側測定）radioimmunoassayで 測定した. ACTHはN 端側測定， C端側測定いずれもVo直後に大分子ACTH存在 を認め，さらにN端側測定では ${ }^{1-39} \mathrm{ACTH} の$ 流出 部位に一致した第 2 のピーク，またC端側測定で ${ }^{1-39} \mathrm{ACTH}$ と $\beta-\mathrm{MSH} の$ 流出部位に一致してさらに

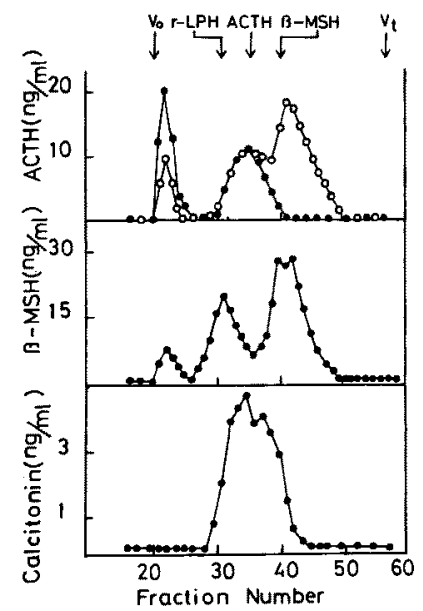

図7.ゲル汇過法によるsize hexerogenityについて の検討。Ⓝ端側測定, OC端側測定
二つのピークが出現した. この事は腫痬に特有 な大分子ACTHが存在することが証明され，ま た C 端側測定では $\beta$-MSHに 流出する部位に一致 $す る C L I P$ (corticotrophin-like-indermediate lobe peptide) の存在が示唆された. 一方, 同一のフ ラクションを $\beta$-MSHの radioimmunoassay で測定 した結果では，Vo直後に大分子のピークがヒト $\gamma$-LPHとB-MSHK一致する 部位に第 2 ，第 $3 の$ ピークが出現した。 これらのピークは各々大分子 $\mathrm{LPH}, \gamma-\mathrm{LPH}, \beta-\mathrm{MSH}$ に相当するものと考えら れた。またCTの測定では ${ }^{1-39} \mathrm{ACTH} の$ 流出部位に 単一のピークが出現し，特にsize heteropenityの 存在は認められなかつた。

家族についての検索 :

剖検の結果患者が典型的なSipple症候群であつ たことが分つたため，患者家族を 3 代にわたり調 查したところ，図8に示したよ5に同胞内に 2 人 が高血圧のため脳卒中で急死しており褐色細胞腫 の存在が疑われた。 また妹が19才で紫斑病で死亡 していたが，高血王や甲状腺腫の有無は不明であ つた，さらに生存する患者の子供 3 人について検 索を行なつたところ，3人とも甲状腺腫や高血圧 は認めず一般臨床検査でも異常は認めなかつた。 尿中カテコールアミンは，第 2 子でフドレナリン (A) $2.5 \mu \mathrm{g} / \mathrm{d}$ ，ノルアドレナリン (NA) $23.4 \mu \mathrm{g} / \mathrm{d}$, 第3 子でA 3.7, NA 26.9，第 4 子でA 7.6, NA

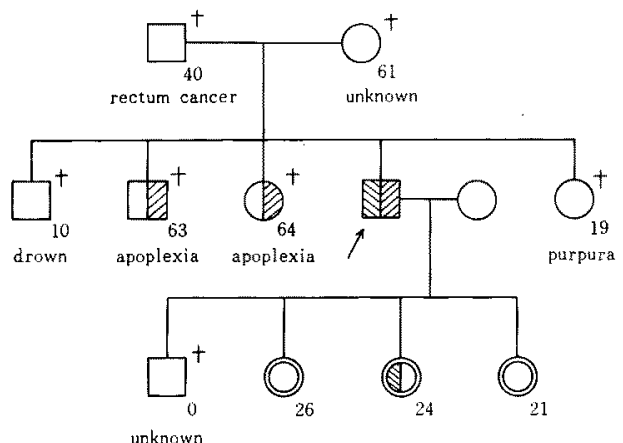

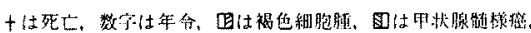

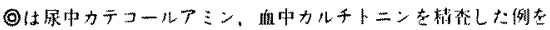
示京。

図 8，家采図を示す。 
$34.2 \mu \mathrm{g} / \mathrm{d}$ と 3 人とも正常值であつた。一方血中 CT值は 3 人とも基礎值 を示したが，Ca，ガストリンによる刺激テスド を行なつたところ，第 $2 、 4$ 子はいずれる異常反 応をしめさなかつたが，第 3 子が負荷直後に 2500 $\mathrm{pg} / \mathrm{ml}$ 異常反応を示した。甲状腺に腫瘤は全く 触知されなかつたが，甲状腺髄样癌の存在を強く 疑い甲状腺全摘除術を施行したところ，甲状腺 両葉中央部に対称性に径 $2 \sim 3 \mathrm{~mm}$ 大の髄様癌の存 在を確認した（第61回日本内科学会信越地方会, 1977年10月, 長岡市にて発表).

\section{3. 考 案}

Sippleが1961年にはじめて，甲状腺癌と褐色細 胞腫の合併が高頻度であることを指摘し ${ }^{2)}, 1965$ 年にWilliamsがこの場合，合併する甲状腺はすべ て髄様癌であることを明らかにした１968年に いたりSteinerらがこの両者の合併を一つの症候 群として確立し, multiple endocrine neoplasia (MEN), type 2 として分類し, 家族性, 常染色体 性の優性遗伝型式をとることが多いことを指摘し た．以来，Sipple症候群として知られ，現在まで に世界で200例以上報告さ礼て扰り ${ }^{5}$ ，本邦では 1976年11月第 9 回の甲状腺外科検討会の全国集計 で28例にいたつていだ .

甲状腺髅様癌は1959年にHazardが初めて独立 した臨床病理的疾患単位として確立し，甲状腺の 他の癌と異なり $\mathrm{C}$ 細胞由来の腫痬で, カルチトニ ンの過剩分泌を伴らのが特徵である ${ }^{9}$. また，C 細胞は正常の場合，甲状腺側葉の中央部，中心線 上に多く分布していて，䯣様癌もこの部位に発生 して来ることが多い，特に本症のようなSipple症 候群の場合は，約70\%の症例で側葉中央部付近に 左右対称性に腫癐が存在し，また多中心性にも腫 瘤が出現してくる．本症に打いても蛍光抗体法 で, 主腫瘤巣の周辺部位に腫瘍化する前段階の C 細胞過形成栄が沪胞上皮細胞間に認められ，癌化 の問題を考えるらえで興味深い所見であつた。

一方, Pearseらは1968年に甲状腺 C 細胞や副腎 䯣質のクローム親和性細胞は, 組織化学的にアミ
ン前駆物質を取り込み，フミノ酸の脱カルボキ シル酵素を多量に含むなどの特徽を有すAPUD系 細胞であると規定しだ．そして，1969年Szijjら は甲状腺髄様癌で異所性にACTHを産生する 1 例 を報告し，APUD系細胞から発生した腫瘍をAPU Doma 総称することを提唱した ${ }^{8)}$.このように, 甲状腺髄様癌の異所性 $\mathrm{ACTH}, \beta-\mathrm{MSH}$ の産生報告 例は, SzijJら ${ }^{8)}$, Williamsら ${ }^{10)}$, Donahwer ${ }^{11} ら を$ はじめとして，本邦でも岩永ら，高井ら，宮内 らと20数例報告されており，臨休的にCushing症 候群を呈した例も認める.著者らの症例は臨床経 過が急激であつたために, Cushing症候はなく，剖 検した副腎皮質も巨大な褐色紐胞腫のため，皮質 の過形成は明らかでなかつたが，臨床上高コルチ ゾール血症や血中 ACTH, $\beta$-MSHの上昇を認め, 䯣様癌組織中にも大量のACTH, $\beta-\mathrm{MSH}$ が検出さ れ, さらに, 䖢光抗体法でもACTH陽性細胞が証 明されたことを考えあわせ，異所性ACTH-MSH 産生甲状腺髄㮏癌であることが確認された。

一方, 褐色細胞腫の異所性ホルモン産生につい てはLiddle 5, Meloni, O'Nealら, Burmeister 5 や平田らなど10数例でACTH， $\beta$-MSHの産生に関 する報告がみられる ${ }^{12)}$ ．な，CT産生については 1970年にKaplanが最初にadrenal medullary calcitonin-like factorの存在を指摘してから，1972年 にMilhaudが 2 例 ${ }^{14)} ， 1973$ 年にVoelkelが 2 例と計 4 例の報告がなされている，興味深いことに， らち 3 例がSipple症候群例であつた。本症例に抏 いては褐色細胞腫に晕様癌の転移が全く認められ なかつたのに拘わらず，組織中に免疫活性のある $\mathrm{ACTH}, \beta-\mathrm{MSH}$ とCTの存在が証明され，さらに ゲル沪過法で大分子ACTH，LPHなど腫瘍によ くみかけるsize heterogenityを認めた。また，蛍 光抗体法でCT陽性細胞が確認された。従つて, 本症は褐色細胞腫からもACTH， $\beta$-MSHとCTが 産生されていた。このよらに甲状腺髄椓癌と褐色 細胞腫から同時にACTH， $\beta$-MSH， CTが同時に 産生された症例の報告は調べた篷团内では見当ら なかつた。これはAPUD系細胞が腫瘍化すると， 
その分化の程度によりAPUD系ホルモンが産生 されてきたものと考える。よつてこれを典型的 なAPUDomaとするか，また藤田らが唱えるparaneuron系細胞由来の腫湟としてparaneuroma とす るか興味深い点である。

本症はMEN type 2 の特徵である副甲状腺の 病変は認めなかつた。しかし，血中Ca，P值は正 常值であつたが，PTHが0.92ng/mlと高值を示し た。市た，䯣様癌や褐色細胞腫中にもPTHの存 在は証明しえなかつた。帆えに，血中PTHの上 异が高カルチトニン血症によつて反応性に出現し た可能性が強いが，その原因を充分火究明しえな かつた。

MEN type 2 では甲状腺髄様癌と同じく, 副腎 の褐色細胞腫は両側性, 多発性が多く, 発生して 来る時も多中心性で，結節性過形成ないしび漫 性過形成の状態から発生してくると言われてい $ろ^{18)}$ 。しかし，本症の場合，両側性であつたが， 巨大な腫瘍と化したためにその経緯を明らかにし えなかつた。

家族内の検索で，患者の長女に乱いてCa，ガス トリン負荷テストで，血中CTが異常反応を示し たことから，全く臨床的に異常症状がなかつた が，甲状腺全摘除に上り微小甲状腺髅様癌を早期 に発見した。全摘した甲状腺の主病巣の周辺部 に, 電顕拉よび蛍光抗体法で C 細胞の過形成巣が 多数散見された。これは，Wolfeらが報告した甲 状腺 C 細胞過形成例よりさらに進行した症例と考 えられる ${ }^{17)}$ 。このように䯣様癌家族については， 臨床的に症状の有無にかかわらず負荷テストを 行ない，血中CT值の異常を検查すべをで，この ことが蹃様癌の早期診断, 治療に大切なことであ ると痛感した。

\section{4. 結 論}

1） 14 年間インスリン治療を受けてきた 58 才の 糖尿病患者が麻瘦性腸閉塞により急死し, 剖検の 結果, 甲状腺髓様癌と副腎褐色細胞腫を合併した Sipple症候群と判明した。

2）臨休的にCushing症候群を伴つていなか
つたが，血中ACTH， $\beta$-MSHとCTが高值を示 し，甲状腺随様癌と褐色細胞腫の組織中から拉の 扣のACTH, $\beta$-MSH, CTの産生が確認された。

3）家族についてCa，カストリン顀荷テストで 娭索したところ，1 例にCTの異常反応が認めら れ，甲状腺全摘術で微小な髄様癌が発見され，早 期に治療し完治しえた。

本研究の一部は厚生省，文部省の癌研究助成金に上 る.

\section{文献}

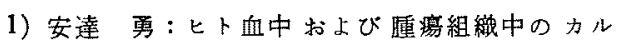
チトニンに関する研究。日内会誌 66: 639, 1977.

2) Sipple JH: The association of pheochromocytoma with carcinoma of the thyroid. Amer J Med 31: 163, 1961.

3) Williams ED: A review of 17 cases of carcinoma of the thyroid and pheochromocytoma. $\mathrm{J}$ clin Path 18: 288, 1965.

4) Steiner AL, et al: Study of a kindred with pheochromocytoma, medullary thyroid carcinoma, hyperparathyroidism and Cushing's disease: Multiple endocrine neoplasia, type 2. Medicine 47: 371, 1968.

5) 高井新一郎, 5: Multipl endocrine neoplasia. 外科治療 $34: 630,1976$.

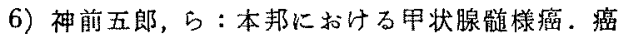
の臨床 $24: 799,1978$.

7) Pearse AGE: The APUD cell concept and its implications in pathology. Sommers, SC, ed. Endocrine Pathology Decennial, 1966 1975, Appleton-Century-Crofts, New York, 1975, p 147.

8) Szijj $T$, et al: Medullary cancer of the thyroid gland associated with hypercorticism. Cancer 24: 167, 1969.

9) Hazard JB: The C-cells (parafollicular cells) of the thyroid gland and medullary thyroid carcinoma. Amer J Path 88: 214, 1977.

10) Williams ED, et al: Thyroid carcinoma and Cushing's syndrome. A case report of two cases with a review of the common features of the "non-endocrine" tumors associated with Cushing's syndrome. J clin Path 21 : 129, 1968.

11) Donahower GF, et al: Medullary carcinoma of the thyroid-a cause of Cushing's syndrome: Report of two cases. J chin Endocrinol Metab 28: 1199, 1968. 
12）佐藤辰男：副腎蹎質腫荡のホルモン異所産生,

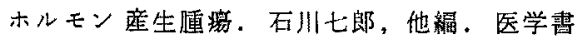
院, 東京, 1977.

13) Kaplan EL, et al: Adrenal medullary calcitomin-like factor: A key to multiple endocrine neoplasia, type 2 Surgery 68: 146, 1970.

14) Milhaud G: Calcitonin disorders and therapeutic use. Talmage, RV \& Mumon, PL, ed. Calcium, Parathyroid Hormone and the Calcitonin, Excerpta Medica, Amsterdam, 1972, p 61

15) Voelkel EF, et al: Concentration of calcitonin and catecholamines in pheochromocy- tomas, a mucosal neuroma and medullary thyroid carcinoma. J clin Endocr Metab 37: $297,1973$.

16) 藤田恒夫 : パラニューロンと APUD 系. 臨床 科学 $13: 1403,1977$.

17) Wolfe $\mathrm{HJ}$, et al: C-cell hyperplasia preceding medullary thyroid carcinoma. New Engl J Med 289: 437, 1973.

18) Carney JA, et al: Bilateral adrenal medullary hyperplasia in multiple endocrine neoplasia. type 2. The precursor of bilateral pheochromocytoma. Mayo Clin Proc 50: 3, 1975. 